\title{
The First International Geological Congress Paris, 1878*
}

\begin{abstract}
The International Geolological Congresses have, for the past 120 years, provided the geological community with an opportunity to create an organizational framework for meeting at regular intervals in a spirit of fraternal cooperation that transcends oceans, languages and wars. This article retraces the history of the first International Geological Congress and also offers some candid and critical reflections on its scientific accomplishments.
\end{abstract}

\section{Introduction}

The need for an International Geological Congress had been recognized for some time before it took place in 1878. As early as 1874, Giovanni Capellini of Bologna had attempted to convene in Italy an international congress aimed at standardizing geological terminology and map colour schemes. In 1867 and again in 1876, Jean Vilanova of Madrid had approached the Geological Society of France with the proposal that an international congress be organized to standardize geological nomenclature.

The decisive push, however, came from America. On August 25, 1876, following the International Exhibition held in Philadelphia the ceremonies commemorating the Independence Centennial, the American Association for the Advancement of Science unanimously adopted the resolution:

"That a Committee of the Association be appointed by the Chair to consider the propriety of holding an International Congress of Geologists at Paris, during the International Exhibition in 1878, for the purpose of getting together comparative collections, maps and sections, and for the settling of obscure points relating to geologicaI classification and nomenclature..." (Am. J. Sci., 1876, v. XII, p. 463).

This committee, later referred to as the "Philadelphia Founding Committee", was made up of the following Americans and Canadians representing the Association: J. William Dawson (Canada), James Hall (USA), Charles H. Hitchcock (USA), T. Sterry Hunt (Canada), John S. Newberry (USA), Raphael Pumpelly (USA), and William B. Rogers. (USA). E.H. von Baumhauer, T.H. Huxley (Great Britain), and Otto M. Torell (Sweden) were associated members. James Hall became Chairman and T. Sterry Hunt the Secretary. A circular printed in English, French, and German was distributed worldwide, but mainly within the various learned societies. It anticipated bringing together (in the Geology section of the Universal Exhibition of Paris) rock collections, fossils, and geological maps and sections as contributions of the participating countries.

Favourable responses to the idea were received from Great Britain, Russia, Sweden, Norway, Austria, Spain, and Italy, and not only from the various geological societies of these countries but from individuals as well. Germany declined to participate, undoubt- edly because of the recent war with France (18701871).

Through its Geological Society, France offered its complete support in helping to organize the Congress. An all-French Organizing Committee was formed from the members of the Society, with E. Hébert as Chairman (Figure 1); R. Tournouer and A. Gaudry as Vice-chairmen; E. Jannetaz as Secretary-General; and A. Delaire, H.E. Sauvage, P. Brocchi, and C. Vélain as Secretaries. Nineteen other members assisted

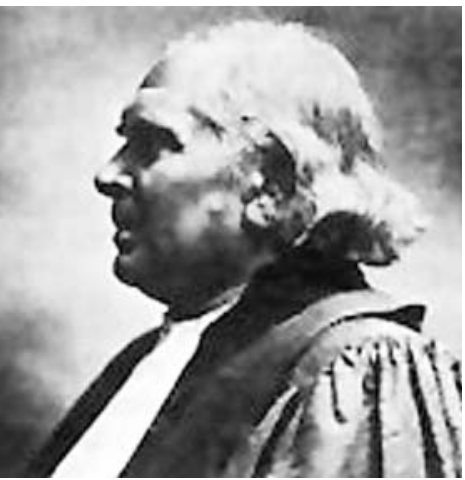

Figure 1 Hébert (France), President of the First International Geological Congress. them. Two circulars were sent out and interested parties (both from France and abroad) were asked to submit in advance lists of suggested topics for debate and outlines of proposed papers. (Am. J. Sci., 1877, XIV, pp.491-493). Registration fees for the Congress were set at twelve francs (12 gold francs being equal to $3.86 \mathrm{~g}$ of gold and worth 109 French francs today [1978]).

\section{The first Congress meets}

And so, the first International Geological Congress materialized: in session from Thursday, August 29 to Wednesday, September 4 of 1878, it was held in Paris in the Congress and Conference wing of the Trocadéro Palace at the Universal International Exhibition (Figure 2). The Presiding Council of the Congress was composed, for the most part, of the above-mentioned members of the Founding Committee, the members of the Organizing Committee, as well as the Chairmen of various national geological societies and major Geological Surveys. At the beginning of the first session, officially opened by the Minister of Public Education, the Board of the Congress was elected. Its make-up was identical to that of the Organizing Committee, plus 14 Vice-Chairmen from foreign countries, namely Canada, the USA., and the major European countries. Both the Chairman, E. Hébert, and E. Jannetaz, the Secretary-General, in turn emphasized that the initiative for organizing the Congress had come from the Philadelphia Committee and that its realization was aided to no mean degree by the efforts of Mr. Sterry Hunt.

The French Committee had sent out more than four thousand circulars all over the world. 312 persons from 22 countries registered; 197 of these were from France, the host country, and twothirds of the participants were in fact members of the Geological Society of France (227 out of 312). The small size of the British and German contingents (three members each) and the relative strength of those from the francophone or latin countries of Europe (includ-

*This paper was first published in Episodes, vol. 1, no. 2, 1978. To provide background for the 31st IGC to be convened in Brazil at the turn of the millennium and as a prelude to the 31st IGC special issue "Geology of South America" this September, we re-publish it here with minor editorial modifications by Dr. J. Aaron. 
ing Rumania) were quite conspicuous. This was mainly because, in spite of the generous impetus given to this first congress by the Americans, linguistic and cultural affinities overcame the more genuine international sentiments which would gradually come to the fore in subsequent congresses.

Logistical reasons prevented the full realization of the initial objective of having an international geological exhibition. A large proportion of the samples and documents displayed at Paris were, in fact, integral parts of the various national exhibits at the Universal Exhibition and thus could not be removed and then re-assembled in one location. The Organizing Committee, however, undertook to publish a "Geologist's Guide to the Universal Exhibition of 1878 and to the Public and Private collections of Paris" (154 pp.) - a comprehensive and detailed catalogue of the objects and specimens on display at that time in the French capital.

In view of the number of registered papers, the general procedures of the Congress called for limiting the time allowed for individual presentations to 15 minutes. Those presented in English or German with written abstracts submitted in advance were to be translated into French by the Board. As it happened, the majority of them were given in French, and all of the texts published in the recorded Proceedings of the Congress were also in French.

\section{Scientific program}

The program of the Congress listed the following issues as topics for debate:

1. Standardization of geologic maps and reports with regard to nomenclature and symbols;

2. Discussion of the boundaries and characteristics of certain rock systems;

3. Representation and coordination of linear features (faults and veins);

4. Respective importance of fauna and flora in the delineation of rock systems; and

5. Importance of the mineralogy and texture of rocks in terms of their origin and age.

In all, 41 papers were presented, but less than half of them dealt directly with the proposed themes. Their printed text lengths varied from one to twenty pages, and about 22 observations made during the sessions were appended; these were rarely more than one page long. The volume comprising the Proceedings was printed by the
National Press of France and was 277 pages long, aside from the Appendices.

\section{Standardization of classification schemes}

The papers and the debates were of uneven scientific depth and value starting with the first theme (the most urgent in the eyes of both the American founders and the French organizers) - concerning the standardization of classification schemes, nomenclature, and the geological symbols - the most important result of the Congress was, undoubtedly, the adoption of resolutions establishing two International Commissions. One was charged with looking into the standardization of geological symbols, and the other, the standardization of geological nomenclature. Each commission was made up of one representative from eleven or twelve nations. Two other commissions, restricted to French nationals only, were responsible for reviewing (for the next International Congress in Bologna in 1881) the rules governing the nomenclature of species both in palaeontology and in mineralogy.

Among the presentations made on the subject of standardization, James Hall's (on the nomenclature of Palaeozoic rock systems in the U.S.A.) is noteworthy. Using as an example the complete Palaeozoic series established for the state of New York, the author stated a number of general principles which seem to have retained their validity. The first concerns his respect for the priority which should be given to research already carried out. The comparative method was seriously threatened at the time, and the concerted efforts of geologists and geological surveys in America were restricted to identifying, within a given region, a series of groups designated according to the areas in which the best outcrops were found, without even the slightest reference to European nomenclature. Painstaking research had enabled Hall to follow each group over long distances from east to west, through all the changes encountered in facies and in thickness as one approached the Mississippi and Pennsylvenia areas. According to him, the totality of this contemporaneous formation had to be taken as the unit of comparison, and not one or the other of its component facies even if they did, quite often, have a clearly distinct fauna. One hundred years later the words of the father of American stratigraphy still ring true.

The Rumanian, Stephanesco, articulating the European viewpoint, affirmed in strong terms the urgency of the problem of standardization of stratigraphic nomenclature in the face of "a battle of

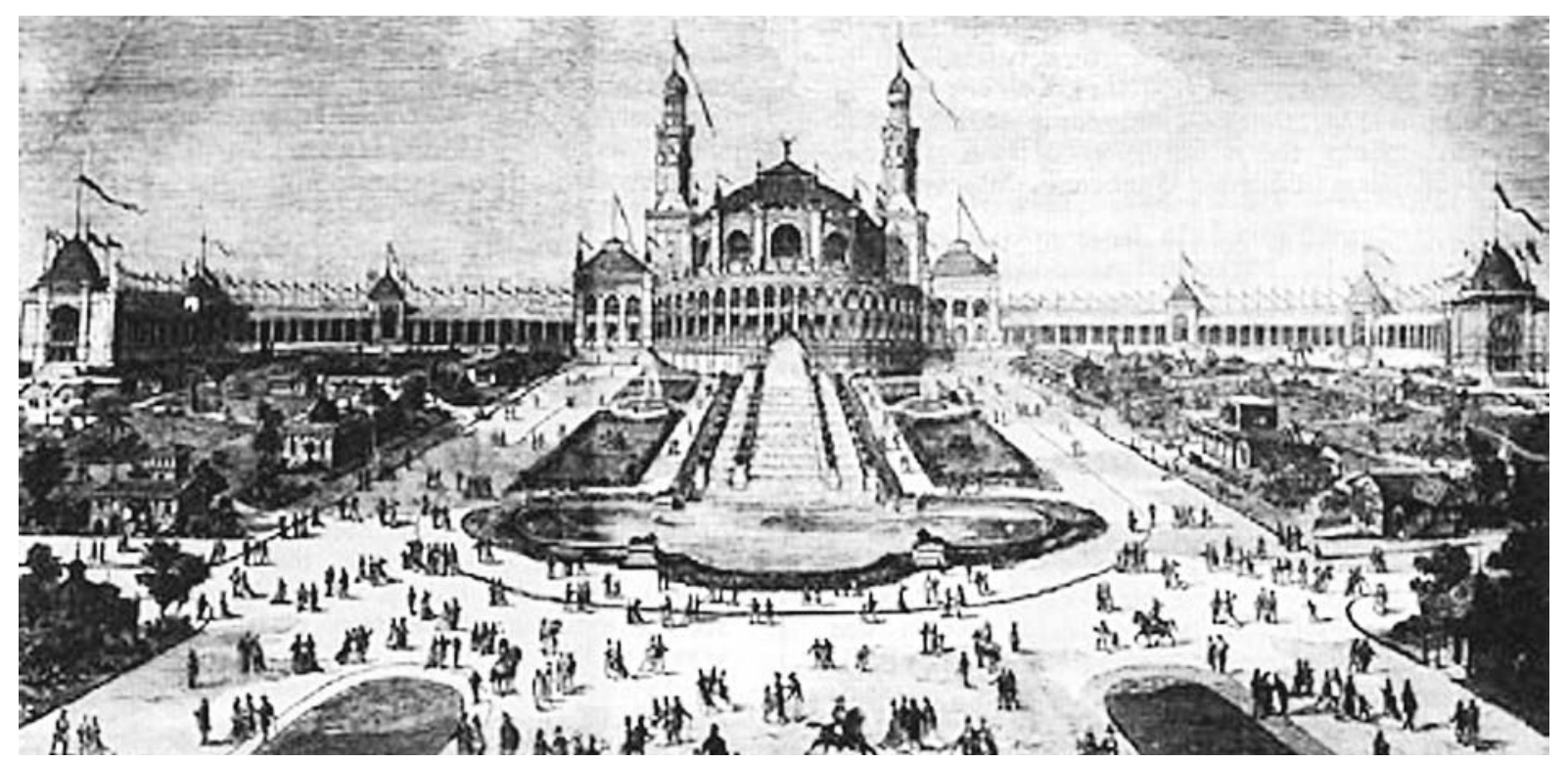

Figure 2 The Universal Exhibition of 1878: Les Palais des Fétes at Trocadéro, site of the First International Geological Congress in 1878. This building was replaced by the present Palais de Chaillot at the Trocadéro in 1937. (Engraving by Bisson after Barclay, Bibliothèque Nationale. Photographed by Harlingue-Viollet and reproduced by permission of H. Roger-Viollet, 6 Rue de Seine, Paris). 
words which confounds the mind, creates disgust for such studies, and threatens us with irremediable confusion." This trend, according to Stephanesco, was the result of anarchistic development of local stage names. The establishment of an International Commission, he felt, offered the only solution.

A number of papers dealt with colour scales; no clear agreement was reached, since the hierarchies of the major geological divisions and systems were themselves still basically undecided. The legitimacy of the Cambrian and Permian systems, fiercely debated by certain eminent Congress participants, serves as an example: even in 1878, the Belgian, Aimé Rutot, found it necessary to uphold the subdivision of the Tertiary System into four parts (Eocene, Oligocene, Miocene, and Pliocene).

To summarize, the real contribution of the Congress to the important theme of nomenclature standardization appeared less in what was said and discussed in the sessions than in the sincere willingness that was expressed to launch a true effort toward reaching agreement. This cooperation is continuing a century later.

\section{Boundaries and characteristics of rock systems}

The second theme concerned the boundaries and characteristics of some rock systems. The problems in question related mainly to the Lower Palaeozoic and to the Permo-Carboniferous. It is a bit surprising to learn that in 1878 the necessity of a Cambrian system was fiercely debated by the eminent geologists at the Paris Congress.

T. Sterry Hunt (Figure 3)

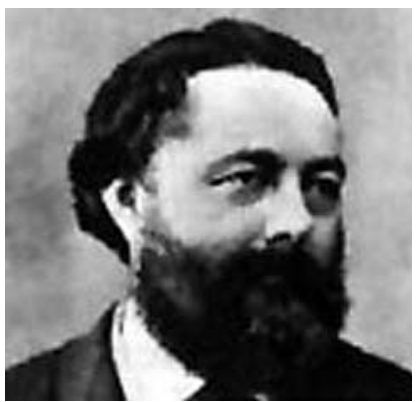

Figure 3 T. Sterry Hunt (Canada) played a key role in the Philadelphia Founding Committee (Photo courtesy GSC 69324).

recalled the historic debate between Sedgwick and Murchison in Wales, the former extending his Cambrian designation up to the Bala group (Caradocian, in fact), while the latter laying claim, within his Silurian designation, to most of Sedgwick's Cambrian (including the Paradoxides beds). This latter boundary was adopted by the Geological Surveys of Britain and Canada. A number of English geologists, however, including LyelI and Hicks, refused to accept this grouping and adhered to a Cambrian period extending up into the Tremadocian. Sterry Hunt nevertheless remained loyal to Sedgwick and to his expanded definition.

J. Barrande with his immense authority as a paleontologist, began his lucid and logical presentation by deploring that "our teachers Murchison and Sedgwick had, neither one, cultivated anything but the field of stratigraphy, and both had neglected that of paleontology". According to him, the field of geology could not be complete without both disciplines. After this, he paid homage to the Americans "who have given us the best example for the study of ancient rock systems", which placed them far ahead of Europe. He felt that their nomenclature, however, although a monument to hard work, was "not applicable precisely worldwide to all Silurian and Palaeozoic rocks". The comparison of one country to another showed that correlation by stage was, in general, impossible to extend for any distance. Paleontology had amply demonstrated the existence everywhere in the lower Palaeozoic (which Barrande placed entirely within the Silurian) of a succession of three major faunas: primary, secondary, and tertiary, based for the most part on the evolution of the Trilobites. According to Barrande, the examination of these major faunal units (unseparated, as they are, by any sharp boundaries) permitted the correction of certain errors (such as the inclusion of the Potsdam stage with the groups immediately below it, or the inclusion of the Tremadocian with the basal faunal unit). As for the discussions on nomenclature, they were completely useless according to Barrande; the terms "Basal Silurian", "Lower Silurian", and "Upper Silurian" were still quite clear and adequate.

E. Hébert then took the floor and declared himself, regretfully, to be of the same opinion. He suggested, however, that the term "Cambrian" be reserved for those semi-crystalline schists found immediately below the Basal Silurian (such as the Brittany-SaintLôphyllites) or, in other words, our Brioverian period.

Insofar as the upper Palaeozoic is concerned, V. Von Moeller, of Saint Petersburg, made an important presentation on the Carboniferous of Russia and its subdivision into two major assemblages, Lower and Upper, with both of them including either marine limestone facies, or alternating marine and coal-bearing strata, depending on the geographic location. Von Moeller showed that the Upper limestone assemblage, characterized by Fusulinids, are the lateral equivalents of the productive Coal Measures of western Europe, and occur immediately below the basal Permian (Artinsk stage). He did not propose, however, any new terms for designating these two divisions, mainly because it was still difficult to recognize their natural subdivision. It was not feasible, according to Von Moeller, to consider either the coal-bearing limestones or the coal beds proper as distinct stages of the Carboniferous system, since they are mutually interchangeable and each encompasses an enormous series of deposits.

Gosselet (France) recalled that the Cephalopoda permitted a more precise dating than that provided by the neritic fauna used by Von Moeller. A. de Lapparent (France), bringing up again the individuality of the Carboniferous system reinforced by the above work, defended the concept of local types and regional stages. He also recalled that the coal-bed flora permitted much finer subdivisions than those based by Von Moeller on marine fauna.

P. Lesley of the USA, referring to recent work on the Carboniferous basin of Pennsylvania, announced the discovery of an upper formation (continuous with the Coal Measures immediately below it) in which limestone beds having a specific fauna occurred. The flora was closely related to that of the Permian in Europe. Thus, within an almost unchanged lithology, a completely different faunal assemblage was to be found. In response, E. Hébert stressed the importance of Lesley's findings which confirmed once again the value of correlations based on paleontology. He also recalled that there was a problem concerning whether or not to keep the name "Permian" or to reestablish the older (1822) term "Penean".

\section{Representation and coordination of linear features}

While these two themes involved the Congress in very fruitful debates, resulting in important contributions, one can hardly say the same for the other three subjects. The third topic (representation and coordination of linear features) attempted to kindle an international debate on a subject which was a source of quarrels solely among the French.

The entire dispute was the legacy of the great Elie de Beaumont, who was overtaken in his later years by a fascination for polygonal geometry related to tectonic episodes (which, curiously enough, has again become the mode). His student, Béguyer de Chancourtois, using as a point of departure some observations made in northern France on the preferred orientation of joints, streams, and the like, defended the strange idealistic concept of a worldwide "Pentagonal Network" (the swan song of the above-mentioned theory and an instructive example of an epidemic hallucinatory conceptualization!).

This network, according to its proponents, was linked to the laws of terrestrial contraction (shrinkage) through cooling. In support of his ideas, de Chancourtois presented to the Congress the experimental picture of rubber balloons, first inflated, then oiled and coated with melted wax, and then partially deflated. In his example, the author perceived "the different characteristics of mountain-like 


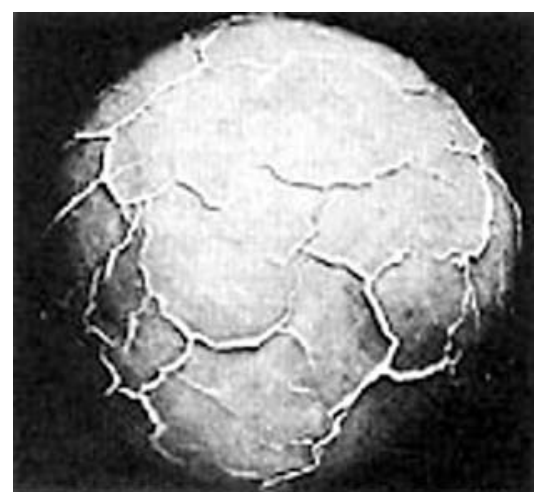

Figure 4 Use of deflating balloon to simulate contracting earth. "First result: a thin crust, tendency toward polygonal forms...". (de Chancourtois; from Stenographically recorded proceedings, $p$. 44-55).

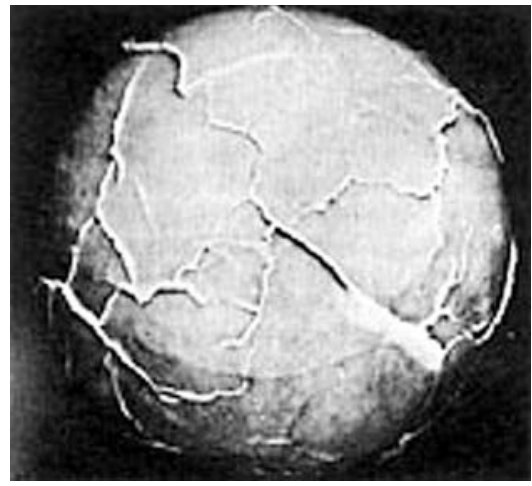

Figure 5 Same as Figure 4, but demonstrating the second result: " $a$ thick crust, tendency toward elongated lineations with overlapping". bulges, formed as much by simple recurving as by puckering or by overlapping of one compartment over those adjacent to it". He noted the almost polygonal aspect of the wrinkles (Figures 4 and 5).

Another Frenchman, A. Daubrée, rigorously described his experiments involving the reproduction, on a small scale, of natural fault and joint networks, notably by the torsion of glass sheets.

\section{Tectonics}

It seems that major geological congresses are often somewhat behind their time. Everyone knows that in 1878 the doctrine of tangential tectonics took a revolutionary turn, coinciding with the discovery of thrusts and, shortly afterwards, the recognition of nappes. Although not included in the program, this problem was brought up by two famous participants.

Charles Lory (France) acknowledged the presence (in the Alps) of major slides in the crust leading to folding of the rock layers caused by gravity, in response to the fracturing of the supporting base by major vertical faults. Alphonse Favre, of Geneva, in linking the orogenic lateral compression to the contraction of the Earth, presented some experimental results in support of this classic theory. A layer of plastic clay, stratified (or grooved along its long axis), was laid on top of a layer of thick rubber and then allowed to retract itself slowly. A faithful image was thus obtained of the folds occurring in the Alps, Jura, Appalachians, and so forth (Figures 6 and 7). Favre related the valid concept of lateral compression to the theory (soon to become outdated) of contraction.

Also worthy of mention were the presentations of d'Albert de Lapparent on the undulations discovered on the seabed at the Pas de Calais (sounded methodically by geologists in connection with the proposed tunnel under the English Channel), and of Charles Barrois on the recurrence of crust movements by south to north compression, both in the Palaeozoic as well as the Oligocene, along the Boulonnais-Ardenne axis.

\section{Fauna and flora}

The topic of "respective importance of fauna and flora" was not dealt with directly. It was used as a pretext for several interesting stratigraphic and paleontological papers. Undoubtedly, the most interesting was that of the American, Edward Cope (USA), entitled "On the relationships seen in the levels of vertebrate extinctions in North America and Europe". This 20-page contribution commented on the stratigraphic distribution of the fossil vertebrates within the U.S.; at the time, these fossils were still scarce in all the Mesozoic, except in the uppermost sequences. He also proposed a correlation scheme for the U.S. and European fauna, thus establishing a stratigraphic synchronism covering the period from Upper Cretaceous to Oligocene.

In another paper, E. Cope attached maximum importance to the extinction of forms, rather than to their initial appearance. He demonstrated the existence (in North America) of formations between the Senonian and the Thanetian that were not represented in Europe.

One should mention as well presentations of Gabriel de Mortillet (France) on "The classification of Quaternary rock systems" according to climate, fauna, industrial uses; of F. C. Winkler (Netherlands) on recent rock systems of Holland; and of E. Vanden Broeck (Belgium) on superficial alteration phenomena produced by percolating ground water.

\section{Mineralogical and textural nature of rocks}

The last theme, on the importance of mineralogical composition and texture of rocks in terms of their origin and age, was curiously sidestepped. The wording of the topic gave the impression that discussions would include the problem of the alleged existence of two series, old and modern, of rocks and of petrographic types (according to Fouqué, Michel-Lévy, Rosenbusch, and others). This was not to be the case.

Among the widely varying papers, that of Edouard Jannetaz (France) on the anisotropic propagation of heat in rocks in relation to their structure could be singled out as worthy of mention. Similarly, Sterry Hunt's paper on the Precambrian rocks of North America (classed according to their presumed order of succession, keeping in

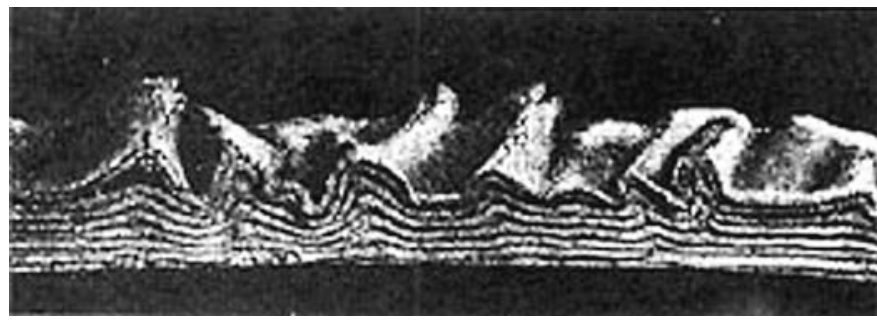

Figure 6 The undulations seen on the surface are the result of folds produced throughout the clay layer. Also visible are valleys of various sizes; arched lines of irregular heights, and more or less warped; broken layers visible at the crest of the arches or of the folds; and finally, caverns resembling certain natural grottoes (A. Favre, from stenographically recorded proceedings, p. 36-37).

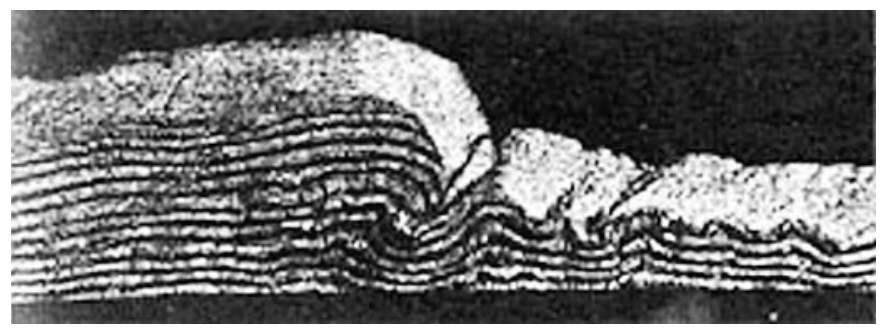

Figure 7 The clay band shown on Figure 6 has been established in such a way that prior to compression, one of the sections had a thickness of $65 \mathrm{~mm}$ throughout, and the other, about $30 \mathrm{~mm}$. These two sections were joined along a very gentle slope .... After the compression, this structure is very similar to that observed on the north-facing slopes of the Alps, at the border of the limestone ranges and that of the Molasse region (A. Favre, from stenographically recorded proceedings, p. 44-45). 
mind their decreasing crystallinity, and excluding all subsequent metamorphism), and that of Szabo (Austro-Hungary Empire) on the relationships between the mineralogical composition and the relative age of the Tertiary (at that time) eruptive rocks of Hungary, were of some interest. Szabo acknowledged the existence of a "cycle of eruption" and of significant rock modifications after deposition.

Finally, outside of the official program, the Congress was given the opportunity to hear a curious memoir read in English by T.C. Chamberlin on the "Kettle Moraine" and its significance for the interpreted movement of glaciers in America.

\section{Conclusion}

Clearly this first International Geological Congress did not succeed as a mechanism for methodically confronting the work and problems then facing the geological community of the world. Several of the major contemporary areas of dispute were not covered by the Paris meeting, topics such as the estimates of the duration of geological periods, the theories and mechanisms of evolution, the nature of the planation of the continents - whether by fluvial or by marine processes, the controversy over eustacy and slow crustal movements, and so forth. Only a few of the Congress papers bore the appearance of up-to-date syntheses presented in the name of a group of researchers from a single country. The themes proposed were often hardly touched upon and were at times replaced by widely disparate presentations of highly variable scientific interest. National representation was very much out of proportion, due largely to the distances involved in travelling to the Congress (from America, Australia, India), the language barriers (French was almost the sole language used at the Congress), political tensions (Germany for example), and other unexplained circumstances (as in the case of Great Britain). Furthermore, the times allotted for papers and discussions were far too limiting.

In short, one can recognize in this first Congress some of the intrinsic problems that have stayed with us to the present day. One might add, too, that the only field excursions proposed to participants and organized by the Geological Society of France for the week following the Congress were a series of day-trips within the Paris region. Only a dozen or so of the foreign participants took part in these.
In spite of all this, the International Geological Congress of 1878 was regarded as a major accomplishment. Aside from the great interest aroused by the papers and discussions, the Congress was hailed as the first, the prototype, of long series of gatherings which neither wars nor the subsequent division of the world into rival blocs were to interrupt to any notable degree for a century. Furthermore, the 1878 Congress, in creating two International Commissions for the standardization of nomenclature and symbols, established the basis of the existing permanent institutions of the IUGS-institutions which are so beneficial to a science in which the tendency toward points of difference, and sometimes, toward dictatorship of a majority, is more evident than in others. Belated thanks, therefore, are due to both the generous American promoters of the Congress, and to the French organizers in the Geological Society of France who were mobilized to bring the concept of an international geological congress to a modest, but effective, fruition.

\section{References consulted}

Am. Jour. Sci., December 1876, v.XII, p. 463.

Am. Jour. Sci., December 1877, v.XIV, p. 491-493.

International Geological Congress, Paris, 29-31 August, and 2-4 September, 1878 , Stenographically recorded proceedings, published by the Central Committee for Congresses and Conferences, Universal International Exhibition of 1878, Paris, National Press, Paris, 313 p.

The late François Ellenberger was Professor of Structural Geology at the University of Paris-Sud-Orsay beginning in 1962, and President of the Geological Society of France in 1972. He was also President of the French Committee for the History of Geology (which he founded in 1976) and an honorary member of the Geological Society of London.

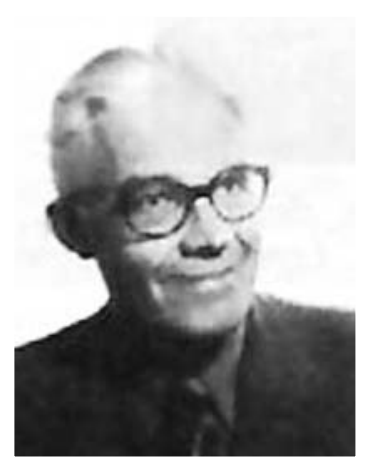

